\title{
Reflections on Technological Continuities: Manuscripts Copied from Printed Books
}

\section{Citation}

Blair, Ann. 2015. "Reflections on Technological Continuities: Manuscripts Copied from Printed Books." Bull John Rylands Lib 91 (1) (April 1): 7-33. doi:10.7227/bjrl.91.1.2.

\section{Published Version}

doi:10.7227/BJRL.91.1.2

\section{Permanent link}

http://nrs.harvard.edu/urn-3:HUL.InstRepos:27715961

\section{Terms of Use}

This article was downloaded from Harvard University's DASH repository, and is made available under the terms and conditions applicable to Open Access Policy Articles, as set forth at http:// nrs.harvard.edu/urn-3:HUL.InstRepos:dash.current.terms-of-use\#OAP

\section{Share Your Story}

The Harvard community has made this article openly available.

Please share how this access benefits you. Submit a story.

Accessibility 
Reflections on technological continuities: Manuscripts copied from printed books

Ann Blair, Harvard University

Abstract: In our time of increasing reliance on digital media the history of the book has a special role to play in studying the codex form and the persistence of old media alongside the growth of new ones. As a contribution to recent work on the continued use of manuscript in the handpress era, I focus on some examples of manuscripts copied from printed books in the Rylands Library and discuss the motivations for making them. Some of these manuscripts were luxury items signaling wealth and prestige, others were made for practical reasons, to own a copy of a book that was hard to buy, or a copy that could be customised in the process of copying. The act of copying itself was also considered to have devotional and/or pedagogical value.

keywords: manuscripts, incunabula, handpress era, printing, Prolianus, Niclaes, Colonna missal, Lucretius, Rylands Library collection

A convenient moment by which to date the emergence of book history as a distinctive subfield is the seminal article published in 1980 by Robert Darnton, 'What is the history of books?' He identified the origins of the field from work in three different areas: the Annales School studies of early modern popular culture through surviving cheap print; the ongoing work of bibliographers and library professionals expert in the study of the books themselves with all their variability; and trends in literature focused on reader response (notably following Hans-Robert Jauss). ${ }^{1}$ Already then Darnton described the field as a multi-disciplinary jungle spreading far and wide with no single path through it. That description is all the more true today, after thirty-five years of remarkable growth from historical, literary, and bibliographical and bibliophilic quarters which has generated countless articles, books, and conferences, a dedicated journal, and an international learned society. ${ }^{2}$ The recent explosion of reference books in the field is especially striking. ${ }^{3}$ New trends in literature and in history (including the rise of cultural history, the material turn, and a new focus on practices) may have played a role. But I have no doubt that the biggest impetus behind the rise of book history in the last two decades comes not from academic developments, but from the broad shared experience we all have, each with differences specific to our field of activity and generation, of living through an ongoing transformation of our media landscape.

The web and digital media are constantly affecting how we own, share, and store texts, how we read and take notes, write and publish. Many of our students are already unfamiliar with reading a newspaper or a scholarly journal in paper rather than electronic form, or with using a photocopier rather than a scanner. At some point the balance in experiencing books will likely shift from paper to various electronic formats too. And yet to understand these new digital tools it is often crucial to understand the media which 
preceded them. One heavily used digital resource, Early English Books Online (EEBO), has transformed research in early modern English texts; but its digitisations reproduce the microfilms made starting in the 1950s from the imprints of the 16th and 17th centuries listed in Pollard and Redgrave's path-breaking Short-Title Catalogue. As a result, to interpret a digital page on EEBO requires familiarity with early printed books and with the impact of the intermediate stage of microfilming; brown pen marks or ink bleeding through the page of the early modern copy became black marks in the microfilm which were then transferred to the electronic version. Even in cases of direct digitisation of old books, which is of course much preferable, to understand fully the digital image requires familiarity with actual books. It is essential therefore to impart to students and all those interested in reading early modern texts some familiarity with the early books themselves. Even outside the study of early printed books, the impact of the codex form is visible in digital media in many ways. For example, e-readers generally mimic the experience of turning the page; this skeuomorph (a technically unnecessary mimicry of an earlier technology) may well outlast the time when users think of themselves (as most of us still do) as transitioning from reading on paper to reading on electronic devices. Indeed word-processors still have functions for 'cutting and pasting' when only a small number of us at this point have actually used scissors and glue to merge documents or turn notes into texts by cutting and pasting bits of paper.

Digital media bring with them many benefits, but also some serious losses. As we increase our reliance on them, an understanding of the history of the book becomes a crucial tool in palliating the decline in direct contact with the original books. We need to teach ourselves and our students how the codex came to be and still shapes the forms we use, how media have been changing for a long time, and how new media often coexist with earlier ones, without necessarily eliminating them, and how co-existing media often have an impact on one another. We also need to allow ourselves and our students as many opportunities as possible to work from the original books, because any form of reproduction introduces distance and distortion, as David McKitterick has shown in his recent book, and some questions can only be answered by accessing the book itself. ${ }^{4}$ Furthermore each copy of an early printed book is unique, due to variations in the printing process before mechanization, and to the frequent presence of annotations made by early owners and readers which offer precious clues about how a text was actually used and read. Dr. Paul White for example has been studying Renaissance commentary by focusing on the marginal annotations in editions of classical authors like Horace in the Rylands collection. ${ }^{5}$ The John Rylands Library with its associated Research Institute is poised to become a leading centre for scholarship and education in book history, given its wonderfully rich and wide-ranging holdings in manuscript and rare printed books from England and Europe but also other parts of the world.

I'd like to illustrate the complex interactions between co-existing media by considering a surprising kind of interaction between manuscript and print in the handpress era, using examples from the Rylands Library. We know how early printed books starting in the 1450 s reproduced the texts and imitated the layout and scripts common in manuscripts of the time. These skeuomorphic features developed from the efforts of early printers to mimic manuscript conventions, thus minimising the perception of difference for readers 
considering choosing a printed book over a manuscript. The imitations of manuscript in print also helped create continuities of format across many centuries (which may even be carried further into some digital media), such as Bibles laid out in two columns, or the use of headings across the top of a page, which became standard in scholastic manuscripts in the thirteenth century. Printed books were thus indebted from the beginning to manuscripts for their content and many aspects of their appearance, though they also developed features distinctive to print. The conventions of the 'modern book' are considered to have become standard by 1530 in Western Europe. ${ }^{6}$

Thanks to a cluster of recent scholarship, we also know about the long persistence of manuscript as a medium of production and publication in early modern Europe alongside printing. ${ }^{7}$ Some kinds of texts were produced for use, circulation, and even for sale in copies made by hand rather than by print. Hand-copying of music scores, which were expensive to print, and often needed in only a few copies, was especially long-lived (indeed down to the recent past when students of jazz copied out scores by hand for distribution in the Real Book in the 1970s in an attempt to circumvent copyright restrictions). ${ }^{8}$ Texts likely to elicit censorship due to religious or political statements were also often circulated in manuscript. Newsletters were produced in manuscript for subscribers, in part to bypass censorship, in part because customers would pay for news reports tailored to their particular interests. ${ }^{9}$ Students produced manuscripts from the courses they attended, often handsomely laid out to look like a printed book. In many cases, manuscripts made after the establishment of conventions for the modern printed book followed the conventions of print: for example seventeenth-century manuscripts generally included title pages and page numbers, which were almost never present in medieval manuscripts, but were standard in printed books. In some seventeenth- and eighteenth-century manuscripts the handwriting is described as quasi-typographical, because it imitated printed fonts, such as Roman or italic. ${ }^{10}$ These fonts had themselves been developed in the early decades of printing to imitate humanist handwriting, but they formed a look of their own, constrained by the separate letter fonts required by typography. So the interplays between manuscript and print were thickly layered.

Amid the flows of mutual influence between manuscript and print in early modern Europe a particularly curious phenomenon has received some attention but might warrant more: the hand-copying of a printed book. ${ }^{11}$ In the handpress era manuscript copies of printed books were more common than one might expect and probably more common than today's equivalent, which would be a printed or paper record of a website. ${ }^{12}$ However, the manuscript copies of printed books are not easy to treat systematically for a number of reasons. A fundamental difficulty is that it is often hard to determine whether a manuscript was copied from a printed book. A manuscript that matches a printed book could have been copied from another manuscript prior or posterior or parallel to the book it resembles. ${ }^{13}$ When a manuscript and a printed copy match, it could also be the manuscript which served as a model for the printed book. After all, any first printing of a text had to be composed from a manuscript, which was supplied by the author, whether an authorial autograph or a copy made by a scribe, which served as the exemplar for the printer. These 'printer's manuscripts' rarely survive, though, since they were typically marked up in the process and then discarded. ${ }^{14}$ Occasionally scholars have identified as a 
printer's manuscript a manuscript that was more likely copied from the printed book in question. ${ }^{15}$ That kind of misinterpretation results in part from insufficient awareness of the phenomenon of copying from printed books, and in part perhaps from the special cachet and value associated with identifying a printer's manuscript.

The potential idiosyncrasies of early printed books and manuscripts are legion, which adds to the complexity of studying relationships between them. The most convincing of evidence of a manuscript copied from a printed book is the presence in the manuscript of bits of text unique to the printed book - license or permission to publish, publication information in the title page or the colophon, or errors typical of typography rather than scribing (e.g. confusions among b, p, d, or q). ${ }^{16}$ It is likely, too, that there were many more manuscript copies made from printed books than we are aware of now, because the manuscripts or in some cases the printed books involved do not survive, and because it is hard to detect a manuscript copy of a printed book. ${ }^{17}$ It is possible that digital cataloging will facilitate the identification of manuscripts made from printed books, by enabling one to look systematically for matches worth investigating between the titles of manuscripts and of printed books within one collection, and ideally across multiple libraries. But at the moment manuscripts from printed books can best be found when the manuscript catalogue is sufficiently detailed to suggest that connection; the increasing searchability of digitised manuscript catalogues greatly facilitates finding references to the phenomenon. ${ }^{18}$ As always, as I experienced in my research at the Rylands Library, the expertise of the librarians in finding such examples is invaluable.

Even when there is clear evidence of copying from a printed source, rarely can the copying be associated with a particular person or context from which to assess motivation, so the discussions of this phenomenon are necessarily speculative, resting in part on other kinds of evidence about the valence of handwriting in the period, and in each specific case on what can be gleaned from the text, the manuscript, and their contexts. I will use several examples of manuscripts from the Rylands Library which reproduced material available in print at the time to illustrate some of the range of forms and likely motives for this practice. Hand-copying was often functional - the least expensive and fastest way to create a copy of a book that could not be purchased for any number of reasons. Hand-copying also produced a unique object which could be customised to the commissioner's preferences. Some early modern manuscripts were produced as luxury or personally significant items which far surpassed their printed equivalents in aesthetic, symbolic, and monetary value. In addition, in some early modern manuscripts the activity of hand-copying itself was valued, either as a pedagogical exercise which aided retention of the text or as a devotional exercise which focused mind and hand on a morally uplifting activity.

\section{Manuscripts copied from incunabula}

During the incunabular period (from the origins of printing to 1500) the interactions between manuscript and print were particularly bidirectional. When humanists came across long-forgotten ancient manuscripts in monastic libraries, they typically made the 
first copy in their own hand, to ensure accuracy and to capture the thrill of those momentous firsts. Their next objective was to have the work printed in an editio princeps, or first edition, ideally by a respected humanist printer. Although they bemoaned the errors introduced by the process, especially when a printer seemed to sacrifice care for speed and the hope of a quicker profit, humanists also hailed printing as a crucial protection against the risk of loss of the kind that had befallen so many ancient texts because the few medieval copies of them had been lost. ${ }^{19}$ By creating hundreds of copies of a text printing greatly improved the odds of its survival, as long as humanist pleas like Gesner's for the formation of libraries were also heeded.

Despite widespread enthusiasm for printing, during the incunabular period a few great bibliophiles continued to commission parchment manuscripts, including manuscripts copied from printed books. ${ }^{20}$ Surviving sources do not include explicit discussion of their motives, but two contemporaries voiced some of the considerations that may have been involved. Johannes Trithemius (1462-1516), a learned abbot who bemoaned the impact of printing more generally, complained that paper would not prove as durable as parchment (and perhaps it will not, but the greater longevity of parchment over fifteenthcentury paper is not yet perceptible from where we stand 500 years later). ${ }^{21}$ And Vespasiano da Bisticci (1421-98), who worked for great Renaissance rulers like Cosimo de Medici and Federigo, Duke of Urbino, to form prestigious libraries for them, commented that manuscripts put printed books to shame 'because they were beautifully illuminated and written on parchment. ${ }^{22}$ Costly manuscripts clearly trumped printed books in the competition for prestige through displays of wealth and patronage in Renaissance Italy. Among them were manuscripts copied from printed books, like the copy that Giuliano da Rovere (later Pope Julius II) commissioned in 1479 of Appian's Civil Wars printed in Speier in 1472; only the colophon was changed from 'impressit Vendelinus' ('Wendelin printed') to 'scripsit Franciscus Tianus' ('Franciscus Tianus wrote'). A few wealthy bibliophiles were responsible for most of the costly manuscripts copied from printed books in the incunabular period. ${ }^{23}$

But even such costly manuscripts could serve functional purposes. Raphael de Marcatellis (1437-1508), one of the natural children of Philip the Good, Duke of Burgundy, was one of the great book collectors of his day, amassing a library of eighty manuscripts, of which fifty-eight are extant. Of these all but ten were copied from printed books. Of these forty-eight manuscripts copied from printed books (sometimes partial copies), more than half the printed books involved are not to be found even today in the libraries of Belgium, where Marcatellis lived and where his manuscripts are now located. In other words he often commissioned manuscript copies of books that were not available for sale in Burgundy or environs - mostly Italian imprints which he borrowed from friends in Italy for the purpose of having a copy made. ${ }^{24}$ Hand-copying could thus serve both to contribute to the most beautiful, prestigious libraries of the day and to transmit a text beyond the zone of circulation of its printed edition.

These cases offer some general context for a unique pair of items owned by the Rylands Library: a 1477 printed Astrologia by Christianus Prolianus and a beautiful parchment manuscript of the same text called 'Astronomia' and dated 1478 (the two terms were used 
interchangeably in this period). ${ }^{25}$ Unfortunately we have no details on the early provenance of either item; the manuscript had previously belonged to the English designer William Morris (1834-96) who may have been inspired by parts of its decoration scheme. ${ }^{26}$ No other manuscripts of this text are known, and the book is rare: USTC lists seventeen copies, including two variants of the colophon and four defective copies. The Rylands copy is also defective, missing pages in the body of the text, which are present in the manuscript. When the manuscript offers a longer version of the tables of astrological oppositions at the back of the book spanning 1478-1515, the discrepancy is due to pages missing from the printed copy at the Rylands, judging from another copy of the work at the Huntington Library. ${ }^{27}$ The odds are high that this manuscript made in the year after the book was printed was based on it. As Michael Reeve points out, 'the chances that a manuscript of the relevant period was copied from a printed edition are in inverse proportion to the number of manuscripts in circulation in the relevant area or the relevant circles before the text was printed. ${ }^{28}$ In this case no other manuscript of the work is known, making a printed source a near certainty; the colophon is also a close match, omitting only the reference to printing and adjusting the date. ${ }^{29}$

[Figures 1 and 2]

About Prolianus little is known; he came from Balvano in Southern Italy and is known for one other text, which survives only in a Latin manuscript miscellany in Paris, noteworthy for his description of the sine quadrant, an Islamic astronomical instrument which he called a 'sexagenarium. ${ }^{, 30}$ Prolianus's Astrologia is a treatise explaining the basics of astronomy and the mathematics required for the discipline in a clear and pedagogical way. ${ }^{31}$ The text was designed to be accompanied by diagrams, but these had to be added in pen into the margins and spaces left blank for the purpose in the printed edition, as they were in the copy in the Rylands Library. This kind of hand-finishing was often arranged by the printer for an extra fee, with the promise of following the authorial model; otherwise one could purchase a copy without the supplements and add them later according to one's own lights. The printed copies at the Rylands and the Huntington Library and the Rylands manuscript all feature similar diagrams in the same places in the text, with small variations in the labelling of points and the colours used. At least these two printed copies and the copy that served as the exemplar for the Rylands manuscript all followed the same template, but scribes introduced variations in the individual copies. In the manuscript the larger images, which featured for example the arrangement of the planets, became occasions for high-quality illumination, and section breaks were highlighted with decorative borders. These enhancements made the text easier to read and understand as well as more beautiful. Although we do not have enough detail to reconstruct a specific context for its production, this manuscript clearly signaled its owner's wealth and prestige with its airy layout, gold leaf, abundant decorations and high quality parchment among other luxurious features. The text itself was useful, but not prestigious and was presumably chosen for the information contained in its chapters, diagrams, and tables.

The cognitive virtues of manuscript copying 
My next example, jumping down to the late sixteenth century, is a very different pair of printed book and manuscript copy. English MS 171 was not produced by a professional scribe but home-made, not in Latin but in English, not on luxurious parchment but on inexpensive paper of small format. The Terra pacis of Hendrik Niclaes (1502-80), a Dutch visionary, was one of the central texts for an underground Protestant sect known as the familists or Family of Love. This and other works of H. N. (identified only by his initials) were first written in 'base almayne', but Terra pacis was printed first in English in 1575 (a copy of which is also in the Rylands Library). Terra pacis was printed in 1580 in its original language and in French, and a second English edition appeared in 1649. ${ }^{32}$ Rylands English MS 171 is a complete copy of the 1575 edition of Terra pacis: a true testification of the spirituall lande of peace, which is the spirituall lande of promyse, reproducing the whole text with title page, marginal references, and closing illustration. Again we have no details on the early provenance or context of the manuscript. ${ }^{33}$ But the nature of the text suggests two reasons for manuscript copying beyond the simple desire to have a copy of the text - the need for secrecy and appreciation for the devotional merits of copying a spiritually uplifting text.

[Figures 3 and 4 side by side and Figures 5 and 6 side by side: title page and closing image from English MS 171 and the printed Terra Pacis] 2 Landscape pages

Familists resembled Anabaptists theologically, in their rejection of the Trinity, of infant baptism, and of established Church hierarchy and authority more generally. Like the Anabaptists, the Familists were abhorred and feared throughout Europe (especially in the Protestant areas where they originated and spread) for undermining the proper religious and political order. The Familists were also notoriously secretive, even willing to hide their true beliefs under interrogation. The difficulty of detecting them made them even more frightening, and scholars are unsure exactly where and how widely sympathies for familism spread. ${ }^{34}$ Secrecy surrounded the publication of Niclaes's; only the 1649 of Terra pacis, published at a time of relaxed enforcement of religious conformity, bore explicit publication information. Only ten extant copies of the 1575 edition are attested in USTC - it was not a widely distributed book, but likely circulated surreptitiously from hand to hand, making acquisition of a printed copy difficult. More generally the works of H. N. survive in various English manuscripts. ${ }^{35}$

Manuscript was the medium of choice to reproduce books that were suspicious or banned and could not be purchased openly. Thanks to a suit over breach of contract we know for example of a stationer who hired a scrivener to make twelve copies of Thomas Scott, Vox populi. Or Newes from Spain (1620), a politically dangerous work that was nonetheless in high demand. ${ }^{36}$ In the most detailed list we have of manuscripts copied from printed books in England before 1640, all but six of the fifty-three items concerned politics and/or religion, with the potential to be problematic, including three copies of Scott's Vox populi and of the equally dangerous Allegations against the surmised title of [Mary] quine of Scotts. ${ }^{37}$ Secrecy may alone account for the manuscript nature of this copy of Terra pacis. 
Nonetheless another factor at work in the production of manuscripts considered edifying by their copyists (like Niclaes's Terra pacis) may be a renewed value placed on copying as an act of devotion and careful attention. Long hours spent in painstaking copying had been the hallmark of devotion in many monastic settings in medieval Europe. Johannes Trithemius called for continuing these habits even in the face of printing:

Printed books will never be the equivalent of handwritten codices, especially since printed books are often deficient in spelling and appearance. The simple reason is that copying by hand involves more diligence and industry. ... The monk, through his dedication in copying, will gain four conspicuous benefits: his time, a most precious commodity, is productively put to use; his mind, while he writes, is illumined; his sentiments are enkindled to total surrender; and after this life he will be crowned with a special reward. ${ }^{38}$

In scholastic contexts in the middle ages, however, scribing was viewed differently, as a form of manual labour to be delegated when possible. Writing was not in itself the purview of the scholar at the university. Albert the Great for example described copying in his own hand as an act of humility. ${ }^{39}$ Thomas Aquinas's handwriting was notoriously illegible and he composed mostly by dictation. In medieval Paris students were discouraged from spending too much time copying. Although they attended sermons at least once a day, they were warned against 'wasting time in writing out sermons other than their own; only one day a week might be spent in sermon writing. ${ }^{40}$ The rules against dictating at the University of Paris (which were observed in the breach given their regular repetition and were finally lifted in the sixteenth century) likely stemmed in part from a similar sense that mere scribing was a waste of time for university students (though acceptable for younger ones). One master caught dictating justified himself by invoking the poverty of those students who could not afford a scribe and thus needed to make their own copy of the texts; hiring a scribe was evidently considered the normal solution. ${ }^{41}$ So attitudes toward handwriting in the middle ages varied by context and type of writing: the painstaking production of beautiful sacred manuscripts in a monastic scriptorium was an act of devotion, while the rapid production of functional manuscripts for the universities was not worth the time and attention of those who could afford to delegate it.

Colette Sirat has argued that an unexpected impact of printing was to raise the status of handwriting in general. Competition from the new technology drove professional scribes in the age of print to promote handwriting as a skill worthy of princes and scholars; they successfully used printed manuals to enhance the prestige and visibility of their services in teaching good handwriting. ${ }^{42}$ Dozens of handwriting manuals were printed in the sixteenth and seventeenth centuries, most of which went through multiple editions, offering not just models of writing to imitate but often a treatise on handwriting (e.g. on preparing and holding the quill, forming the letters in different scripts, the joins, the slope, etc.) which frequently opened with a justification for learning these skills. ${ }^{43}$ Many writing manuals emphasised that bad handwriting would make a reader ill-disposed to the arguments he or she was reading; and conversely that a good hand would predispose the reader favourably. ${ }^{44}$ In the most ambitious such statement, the Basque Madariaga who 
dedicated his Libro subtilissimo to Philip II in 1565, called handwriting a liberal art, because it opened the way to higher disciplines and was an appropriate pursuit for a gentleman along with fencing, swimming, and dancing. He argued that penmanship should even 'be given a place among the supreme accomplishments and inspired sciences close to holy Theology' since it was a divine gift and God himself was a scribe, having written in his own hand the tablets of the law that he gave to Moses. ${ }^{45}$

The arguments of these scribes gained support from humanist pedagogues like Erasmus and Juan Luis Vives who portrayed handwriting as an essential personal skill and a valuable intellectual exercise. Humanist pedagogues praised handwriting as an act of mental and manual discipline that enhanced the retention of the material. Erasmus blamed the decline of proper handwriting among scholars on printing and highlighted the virtues of writing in one's own hand - privacy, control, evidence of authenticity and personal investment - for example in this passage of a pedagogical dialogue:

Leo: Nowadays the art of printing has led to the situation that some scholars do not write down anything at all! for if they decide to commit any of their lucubrations to paper, they write so beautifully [ironic] that they themselves cannot read what they have written and require a secretary to read it and decipher what they cannot decipher themselves. ...

To be brief: a letter that is a product of someone else's fingers hardly deserves the name. For secretaries import a great deal of their own. If you dictate verbatim, then it is goodbye to your privacy; and so you disguise some things and suppress others in order to avoid having an unwanted confidant. Hence, quite apart from the problem of the genuineness of the text, no open conversation with a friend is possible here. It is very easy to forge a signature but very difficult to forge a complete letter. A man's handwriting, like his voice, has a special, individual quality. ${ }^{46}$

Juan Luis Vives also promoted learning to write in a dialogue in simple Latin designed for the instruction of boys (Linguae latinae exercitatio, 1538) in which the master tells his well-born charges that 'you will attain true nobility if you train your minds with those accomplishments which are particularly appropriate to your noble lineage' - among them handwriting. ${ }^{47}$ Similarly theorists of note-taking, humanist and Jesuit pedagogues, argued that note-taking aided the memory in two different ways: not only by creating a written record to return to, but also by forcing the mind to dwell on the material and to retain better what was read or heard by writing it down. Francesco Sacchini and Jeremias Drexel, the Jesuit authors of the two most reprinted manuals on note-taking, made this point repeatedly. ${ }^{48}$ In support of the pedagogical virtues of writing Sacchini cited the model of ancients who copied texts not in order to have copies of them, but in order to retain them better. He reports (citing Dionysius of Halicarnassus) that Demosthenes copied Thucydides eight times, and Saint Jerome wrote many volumes in his own hand, "not due to the weakness of his library but out of desire to profit from the exercise. ${ }^{49}$ The sentiment was widely shared by other pedagogues, from Juan Luis Vives, who also praised the act of copying for keeping light or scabrous thoughts at bay ${ }^{50}$ to New England preacher Richard Steele who wrote in 1682: 'the very writing of any thing fixes it deeper in the mind. ${ }^{51}$ 
English MS 171 with its functional and personal copy of an underground spiritual text is the kind of work that resulted from writing as note-taking. The writing was meant to create a new copy, of course, but also included the benefit of a close personal engagement with the text and its spiritual message. The care with which the closing image was reproduced from the printed book, for example, indicates that producing an intelligible copy of the model was not the only goal. The image could have been merely sketched to convey its meaning. Instead its careful finish suggests a devotional commitment to the process of copying itself. The Catholic monk Trithemius would not have approved of the result (neither its content nor its form), but some of the reasons for his attachment to handwriting were reformulated by humanist pedagogues who would have recognised this manuscript as a valuable product and practice.

\section{[Figures 7 and 8] Side by side}

The copying from printed books also is exemplified among the rich holdings of the Rylands library in non-European languages. Levinus Warner (1618-65), originally from Lippe in Germany, studied Arabic at the University of Leiden, thanks to the teaching recently set up there, and spent most of his adult life in Istanbul, serving the Dutch states as an unofficial and later an official source of information from the Ottoman Empire. While abroad Warner also amassed a large collection of Turkish, Arabic, and Persian books. ${ }^{52}$ Rylands Persian MS 141 contains a copy of Warner's Proverbiorum et sententiarum persicarum centuria (Leiden: Joannes Maire, 1644) which reproduces the one hundred Persian proverbs in Arabic script with Latin translation. ${ }^{53}$ The manuscript copy, on forty-four large folio pages, is carefully written, with ample blank space on each page, whether for elegance of presentation or for the possibility of marginal annotations which were never added. But the writer also customised the copy by omitting the commentary present after each proverb and translation in the printed original.

Warner's printed work is supplemented with seven other shorter items in the manuscript volume: a Persian grammar by Franciscus de Dombay (1758-1810), an Austrian orientialist and dragoman, and six shorter collections of proverbs, never published, likely also gathered by Warner --one set of fifty Persian proverbs, and five sets totaling 440 Turkish proverbs, all with Latin translations. ${ }^{54}$ The manuscript grammar entitled "Rudimenta Linguae Persicae" was unpublished at the time; it is similar in broad outline to the Persian grammar which Dombay published in 1804, but different in many particulars. ${ }^{55}$ All the parts of Persian MS 141 are written in the same hand, probably by Dombay himself, who was likely also responsible for a few other manuscripts found in the Rylands collection. ${ }^{56}$ Persian MS 141 thus dates from the late 18 th century, some 150 years after the publication of Warner's book of proverbs that it includes. Handcopying made it easy to bring together a recent grammar with collections of proverbs from the previous century into one useful volume for the study of Persian and Turkish. The manuscript was laid out with ample space for later additions and annotations, though none are present. Perhaps Dombay copied this manuscript for his own use, perhaps to share with others studying in this area; in any case the act of writing it, which drew on 
Dombay's unusual expertise and would have been hard to delegate, was integral to his mastery of the material.

From luxury to miscellany: manuscripts as opportunities to customise

In closing I will consider manuscripts that reproduced material available in print, although they were not presented as direct copies of a particular printed book. Parchment manuscripts became increasingly uncommon after the late fifteenth century when a handful of grandees still commissioned them on a regular basis. Books of hours, central to Catholic devotion, are the principal genre in which the parchment manuscript was commissioned and used beyond the circles of the highest elite, even though books of hours were also among the early genres to appear in print. ${ }^{57}$ Among the many fine manuscript books of hours in the Rylands collection (most of which date from before 1540) Latin MS 152 offers unusual insight into one late example. This book of hours written on vellum in 1581 at a monastery in Nuremberg was inscribed in 1597 explaining that it was a gift from the owner's brother 'by some commissary, that I might remember him in my prayers. ${ }^{, 58}$ The beads attached to breakpoints in the text indicate that it was designed as an object of both devotion and regular use. These handy and beautiful books, often of small format, could of course remain in use long after their initial production, though since these books were rarely annotated, late usage is hard to document.

\section{[Figure 9]}

One source of production of large illuminated parchment manuscripts throughout the handpress era was the papal scriptorium at the Vatican which remained in operation until Napoleon's invasion in 1798. That invasion resulted in the dispersal of the Vatican collection of costly manuscripts. The only manuscripts left behind by the looting soldiers were those made for the Sistine singers which were not as lavishly produced. ${ }^{59}$ But the Colonna missal apparently stayed in the possession of the Colonna family until the late nineteenth century. Produced in seven volumes between 1517 and 1555, it is now complete in the Rylands Library. ${ }^{60}$ The missal as a text was long since available in print when this manuscript was made. The purpose of this and other missals like it produced by the Vatican scriptorium was to mark the promotion of its commissioner to the rank of cardinal. This manuscript was commissioned by Pompeo Colonna (1479-1532) at his appointment to the red hat in 1517. Pompeo came from a patrician family with roots in Rome and Naples which included eighteen other cardinals between 1193 and 1766, nine of them before Pompeo's appointment and another nine after him. The long-running hostility between the Medici and Colonna families resulted in Pompeo's excommunication by the Medici pope Clement VII in 1526, though he was reinstated ca. 1527 before or just after the sack of Rome during which he helped to palliate the damage to the Vatican. ${ }^{61}$

[Figures 10 and 11] 
Pompeo did not live to see the manuscript completed. Although much of the work was finished by 1532, the only colophon appears in the fifth volume, written by Paulus Rochus of Venice, scribe in the chapel of Pope Paul IV, and dated 1555. That colophon also clearly contains an erasure, which M. R. James surmises may be due to the scribe's recent adjustment to working for Paul IV who succeeded Paul III just that year; in other words Rochus may have corrected a III (or 'tertii') to the abbreviation for 'quarti' which appears there now, to bring the work up to date or because he had initially written the wrong number out of habit. ${ }^{62}$ The manuscript was in any case also an investment in prestige for the long term, designed to signal the wealth and power of the Colonna family long after the details of its commissioner's life and the ecclesiastical and international politics of his day were forgotten. The large size of the pages, script, and illuminations signaled luxury but also facilitated use of the missal in the performance of mass in the Sistine Chapel. Specialised artists from the Vatican scriptorium were employed as scribes and illuminators; most of the latter remained anonymous. These objects of great beauty and value served as show pieces to outlast the individuals who commissioned them. ${ }^{63}$

A late parchment manuscript did not have to be large in size to impress. Rylands Library Latin MS 143 is a small and slim parchment manuscript containing Lucretius's De rerum natura, of exquisite execution. The colophon dated 1672 identifies the scribe as Dephainx. This Lucretius manuscript appears in 1791 in the library catalogue of the deceased M. de Lamoignon, a high-ranking official of the Ancien Régime France. ${ }^{64}$ Dephainx is probably the same scribe who made a manuscript copy of François Blondel, L'art de jetter les bombes (Paris: Langlois, 1683) as a presentation copy to Louis XIV. ${ }^{65}$ Louis XIV considered simple books unworthy of his grandeur: when Colbert wished the King to carry around account ledgers, he had them copied into vellum notebooks with illuminations so that Louis XIV would be willing to use them. ${ }^{66}$ A 'Dephainx fils' (presumably the son of our scribe) is noted for two drawings of engravings from the 1730 s. ${ }^{67}$ Given that Lucretius's De rerum natura was long considered an atheist text, it was certainly not selected as a devotional work, though it is treated with the same care as one might be. By 1672 when this copy was made, the Parisian salons were abuzz with Cartesianism, and Lucretius may have held special appeal as an authoritative ancient text that nonetheless challenged standard Christian and Aristotelian notions. To commission such a beautiful and easily carried copy of it suggests a desire not only for ostentation but also for a personal and aesthetic connection to that work of ancient philosophy.

\section{[Figure 12]}

Aside from exceptional luxury items large and small, the majority of manuscripts in the age of print were made on paper. One of the great advantages of manuscript was the ability to customise indefinitely: when copying from books the manuscript could select the parts of interest (as Persian MS 141 did in omitting the commentaries present in the printed source) and combine materials from printed books or other manuscripts with new compositions. Latin MS 82 offers an example of such a miscellany, written in multiple hands, from multiple sources, including some English verse, much Latin prose, a few coloured illustrations, and a few printed engravings made for Heinrich Khunrath's Amphitheatrum sapientiae aeternae (1602), which were probably either purchased 
separately or cut out from a copy of the printed book. Miscellanies were especially common in alchemy, a field in which individuals experimented with ideas (and actual substances) by drawing on personal inspiration as well as printed and manuscript sources. Alchemy was also considered suspect in many early modern contexts and furthermore the profits one hoped to make from any successes were better kept closely guarded; as a result manuscript was often preferred to print for alchemical works. ${ }^{68}$

[Figure 13 and 14]

In closing

Manuscripts copied from printed books or reproducing content available in print were produced throughout the handpress era (and much later too, down to the present). They are a reminder that old media persist even if new media become dominant, and despite various advantages new media do not capture all the features of the old. Neither print nor the codex form are at risk of disappearing in the near future, it seems to me, nor even the use of handwriting, though it may decline with the proliferation of keyboards. We can weather the transition to new media with greater equanimity, I suggest, in the knowledge that great collections of books and manuscripts like the Rylands Library will serve as centres for the transmission and continued cultivation of our knowledge about the history of books and for the investigation of the myriad questions these mute but eloquent objects invite. Despite ever improved technologies of reproduction there is no substitute for studying the old books themselves. Book historians have only started to explore in new ways the many clues they carry and we can hope that future generations of scholars will pose still other fruitful questions. In embracing new media we must never discard the old ones, especially those manuscripts and early printed books which a complex chain of preservation, gift, and sale has brought down to us. I wish a long and productive future from the Rylands Library Research Institute which can draw on a vast trove of treasures, full of mysteries to be elucidated, and on the expertise and energy of its dedicated staff of specialists in manuscripts, printed books, and imaging technologies.

\section{Acknowledgements}

I thoroughly enjoyed my first introduction in March 2014 to Manchester and its remarkable libraries. Special thanks to Professor Peter E. Pormann for the invitation, to the many Manchester colleagues who extended such a warm welcome to me during my visit, and to the librarians who not only guard rich treasures but also make them available for consultation. I am grateful for help in the research for my talk and the preparation of this written version especially to Elizabeth Gow and John Hodgson of the Rylands Library, to Samantha Wesner at Harvard, to Richard Kremer and Melissa Lo for email consultations on the Prolianus example, and to Peter Pormann, Sasha Handley, and Paul Fouracre for their kind support throughout. 
${ }^{1}$ Robert Darnton, 'What is the History of Books?' Daedalus 111:3 (1982), 65-83; reprinted in his The Kiss of Lamourette: Reflections in Cultural History (New York: Norton, 1990), pp. 107-35.

${ }^{2}$ Book History is annual periodical founded in 1998. SHARP is the Society for the History of Authorship, Reading, and Publishing, founded in 1993.

${ }^{3}$ The number of recent reference works in this area is especially striking. See for example The Oxford Companion to the Book, ed. Michael Suarez and Henry Woodhuysen (Oxford: Oxford University Press, 2010); A Companion to the History of the Book, ed. Simon Eliot and Jonathan Rose (London: Wiley-Blackwell, 2009); The Broadview Reader in Book History, ed. Michelle Levy and Tom Mole (Peterborough ON: Broadview Press, 2014); Handbook for the Study of Book History in the United States, ed. Ronald J. Zboray and Mary Saracino Zboray (Washington DC: Center for the Book, Library of Congress, 2000); The Book History Reader, ed. David Finkelstein and Alistair McCleery (London: Routledge, 2006); Dictionnaire encyclopédique du livre, ed. Pascal Fouché, Daniel Péchoin, Philippe Schuwer (Paris: Edition du Cercle de la Librairie, 2002-11).

${ }^{4}$ David McKitterick, Old Books, New Technologies : the representation, conservation and transformation of books since 1700 (Cambridge: Cambridge University Press, 2013).

${ }^{5}$ His work at the Rylands Library Institute will appear in a forthcoming article entitled 'Reading Horace in 1490s Padua: Willibald Pirckheimer, Joannes Calphurnius and Raphael Regius'.

${ }^{6}$ David McKitterick, Print, Manuscript, and the Search for Order, 1450-1830 (Cambridge University Press, 2003); Henri-Jean Martin, La naissance du livre moderne : (XIVe-XVIIe siècles) : mise en page et mise en texte du livre français (Paris: Editions du Cercle de la Librarie, 2000).

${ }^{7}$ Harold Love, Scribal publication in seventeenth-century England (Oxford: Clarendon Press, 1993) and The Culture and Commerce of Texts: Scribal Publication in Seventeenth Century England (Amherst MA: University of Massachusetts Press, 1998); Peter Beal, In Praise of Scribes: manuscripts and their makers in 17th-century England (Oxford:

Clarendon Press, 1998).

8 In the absence of scholarly discussion of the Real book see http://en.wikipedia.org/wiki/Real_Book\#History_of_the_.27original.27_Real_Book. For examples of early modern music copied from printed sources, see the discussion of motets copied from Ottaviano Petrucci, Motteti A (Venice, 1502) in Julie Cumming, 'From Chapel Choirbook to Print Partbook and Back Again', in Cappelle musicali fra corte, Stato e Chiesa nell'Italia del Rinascimento: Atti del convegno internazionale di studi, Camaiore, 21-23 ottobre 2005, ed. Franco Piperno, Gabrielle Biagi Ravenni, and Andrea Chegai (Florence: Olschki, 2007), pp. 273-403, at pp. 384 and 391-93. I am grateful to Kate van Orden for this reference.

${ }^{9}$ Dawks's Newsletter, in print from 1696 to 1716 , used a special font to mimic the cursive handwriting of manuscript newsletters; see Stanley Morison, Ichabod Dawks and his News-letter (Cambridge: Cambridge University Press, 1931).

${ }^{10}$ Examples of such scripts at Harvard's Houghton library include: John Taylor, 'Verbum sempiternum', ca. 1615, scribed by the remarkable Huguenot calligrapher Esther Inglis; Jean Guérard, 'Les commencemens de l'hidrographie, ou Art de naviger' (c. 1630), on 
parchment with colourful tables and map; Sieur de St Martin, 'Le système des cieux, et des elemens, en vers françois' [n. d. not before 1651], on paper, with some illuminations. ${ }^{11}$ See James O'Donnell, Avatars of the Word (Cambridge MA: Harvard University Press, 1998), pp. 76-79; Albert Derolez, 'The copying of printed books for humanistic bibliophiles in the fifteenth century', in From Script to Book. A Symposium (Odense: Odense University Press, 1986), pp. 140-60; and M. D. Reeve, 'Manuscripts copied from printed books', in J. B. Trapp ed., Manuscripts in the fifty years after the invention of printing (London: Warburg Institute, 1983), pp. 12-20, reprinted with minor changes in the footnotes in his Manuscripts and Methods. Essays on Editing and Transmission (Rome: Edizioni di Storia e Letteratura, 2011), 175-83. My references to Reeve are to this 2011 version of his article. See also Curt Bühler, The Fifteenth-Century Book: the scribes, the printers, the decorators (Philadelphia: University of Pennsylvania Press, 1960), pp. 34-39; and Cora Lutz, 'Manuscripts copied from printed books', Yale University Library Gazette 49:3 (1975), pp. 261-67, reprinted in her Essays on Manuscripts and Rare Books (Hamden CT: Archon Books, 1975), 129-38; my references to Lutz are to her article in the Yale University Library Gazette.

${ }^{12}$ One area where digital to paper has been practiced as more than a personal idiosyncrasy is in the design of board games that reproduce successful video games; see for example 'Civilization: The Boardgame' as discussed here http://en.wikipedia.org/wiki/Civilization:_The_Boardgame.

${ }^{13}$ For examples of manuscripts copied from an intermediate source, see J. K. Moore, Primary Materials Relating to Copy and Print in English Books of the 16th and 17th Centuries. OBS Occasional publication 24 (1992), p. 1.

${ }^{14}$ Lotte Hellinga, 'Manuscripts in the hands of printers', in Manuscripts in the Fifty Years after the Invention of Printing, ed. J. B. Trapp (London: The Warburg Institute, 1983), pp. 3-11. For discussion of one fine printer's manuscript which was treated with care and can be compared with the printed edition that resulted at the Beinecke Library (both now available digitally), see Lutz, pp. 262-63.

${ }^{15}$ For example see the analysis of a manuscript section of eleven pages in a copy of the 1483 edition of Eusebius's Chronicon at Harvard's Houghton Library, in Paolo Pellegrini, 'Philology and ars artificialiter scribendi: re-covering printer's setting copies (Harvard, Houghton Library, typ inc. 4390)', forthcoming Harvard Library Bulletin. Pellegrini very plausibly concludes that this manuscript section was copied from (rather than serving as the model for, as an earlier analysis had proposed) a 1512 edition of the Chronicon which contained an extension of the historical account down to 1512. Instead of buying the new edition entire, this owner of the 1483 edition preferred to add the new material by hand from a copy of the later edition that he was able to see.

${ }^{16}$ For examples see Reeve, pp. 179-80.

${ }^{17}$ For cases of manuscript copies of printed books which do not survive, see Moore, p. 4 and Bühler, pp. 38-39.

${ }^{18}$ In the digitised catalogues of the manuscripts of the Bayerische Staatsbibliothek I had some success by searching for the Latin term apograph - ('copied'), which turned up some sixteen manuscripts designated as copied from printed books.

${ }^{19}$ For Erasmus's famous attack on printers in general while singling out Aldus Manutius for praise, see 'Festina lente' ('Make haste slowly'), Adage II.1.1 in Erasmus. Adages, 
ed. William Barker (Toronto: Toronto University Press, 2001), pp. 145-46. Conrad Gesner articulated his hope for preservation thanks to printing and libraries funded by grandees in his Bibliotheca universalis (Zurich: Froschauer, 1545), sig *3r.

${ }^{20}$ On attitudes toward printing see Elizabeth Eisenstein, Divine Art, Infernal Machine: the reception of printing in the West from first impressions to the sense of an ending (Philadelphia: University of Pennsylvania Press, 2011).

${ }^{21}$ Johannes Trithemius, In Praise of Scribes. De laude scriptorum, tr. R. Behrendt (Lawrence, KS: Coronado Press, 1974), 35, 63; see O'Donnell, p. 81.

${ }^{22}$ Vespasiano da Bisticci, Renaissance Princes, Popes, and Prelates. The Vespasiano Memoirs, tr. W. George and E. Waters (New York: Harper Torchbooks, 1963), p. 104.

${ }^{23}$ Sigfrid Henry Steinberg, Five Hundred Years of Printing, 3rd ed. (Harmondsworth: Penguin Books, 1974), p. 44; O'Donnell, p. 78.

${ }^{24}$ Derolez, pp. 144-46, 160; also his The Library of Raphael de Marcatellis (Ghent: E. Story-Scientia, 1979).

${ }^{25}$ Christianus Prolianus, Astrologia (Naples: Henricus Alding, 25 Aug. 1477). Rylands

Library Inc 17.B.7 of which one opening is digitised

http://enriqueta.man.ac.uk:8180/luna/servlet/s/73wqau

and Rylands Library Latin MS 53, fully digitised

http://enriqueta.man.ac.uk:8180/luna/servlet/s/di067j

26 J. W. Robinson, 'Christianus Prolianus “Astronomia” 1478.' Retrieved on September 25, 2014, from http://chiccmanchester.wordpress.com/2011/11/23/christianus-prolianusastronomia-1478/.For other blog discussions of this manuscript see John Hodgson, 'Christianus Prolianus' Manuscript Now Digitised', May 19, 2012.

https://rylandscollections.wordpress.com/2012/05/ and Kenneth Hoyt, 'Manuscript Study: Christianus Prolianus' Astrologia' (San Jose State University, 2012): http://prolianusastrologia.blogspot.com/.

${ }^{27}$ A copy of the printed book (call \# 101703) at the Huntington Library contains tables down to 1515 and very similar diagrams added by hand, only rendered more colourfully than in the Rylands copy. I am grateful to Melissa Lo for consulting the Huntington Library copy on my behalf.

28 Reeve, p. 177.

29 'Finis huius opusculi Parthenope Anno salutis 1478 foeliciter Amen.'

${ }^{30}$ See Maravillas Aquiar Aquilar and José Antonio González Marrero, 'Un tratado latino sobre los usos del cuadrante de senos: edición de los cánones del tratado de Christianus de Prolianus conservado en el ms. lat. n. 10263 de la Biblioteca nacional de Francia', Faventia 27:1 (2005): 113-23; and Lynn Thorndike, 'Sexagenarium', Isis 42:2 (1951): 130-33.

${ }^{31}$ See Giuseppe Giovanni Monaco, 'Christianus Prolianus balbanensis e 1'Astrologiae Compendium', Bollettino storico della Basilicata (Venosa) 15-16 (1999-2000): 113-44. Prolianus will also feature in Richard Kremer, 'Practical Knowledge and Practica-Making in the Early Decades of Printing', in Structures of Practical Knowledge, ed. Matteo Valleriani, forthcoming from the Max Planck Institut für Wissenschaftsgeschichte. Kremer has determined that Prolianus likely based his computations on the Alfonsine tables which he converted to Italian hours (with days starting at sunset rather than at noon). Prolianus's eclipse and syzygy times would have been useful for those drawing up 
almanacs, although we do not know of any incunable almanacs printed in Naples. I am most grateful to Richard Kremer for his expert correspondence with me on these points.

${ }^{32}$ The 1575 edition carries no details of publication; modern cataloging reports Cologne?: N. Bohmberg, 1575 (or 1574); the other bears the imprint of London: Samuel Satterthwaite, 1649. Both are available on EEBO. See also Terra pacis. Ware getuegenisse van idt geistelicke landtschop des fredes (Cologne: N. Bohmberg, 1580) and Terra pacis. Vrai tesmoignange de la terre spirituelle de paix (Cologne: N. Bohmberg, 1580), according to USTC.

${ }^{33}$ The catalogue suggests that the manuscript is copied from the edition of 1649 , but the layout of the manuscript title and closing pages carefully mimics that of 1575 rather than 1649 , indicating that the earlier edition was the source.

${ }^{34}$ Christopher Marsh, The Family of Love in English Society, 1550-1630 (Cambridge: Cambridge University Press, 1994), pp. 1, 5, 8.

${ }^{35}$ Alastair Hamilton, The Family of Love (Cambridge: J. Clarke, 1981), pp. 137 and 16667. He lists sixteen English manuscripts of work of H. N., though none of Terra pacis.

${ }^{36}$ H. R. Woudhuysen, Sir Philip Sidney and the Circulation of Manuscripts 1558-1640 (Oxford: Clarendon, 1996), p. 52.

${ }^{37}$ Moore, pp. 1-9

${ }^{38}$ Trithemius, In Praise of Scribes, pp. 65, 61.

${ }^{39}$ Monique-Cécile Garand, 'Auteurs latins et autographes des XIe et XIIe siècles', Scrittura e civiltà 5 (1981), p. 191.

${ }^{40}$ D. L. d'Avray, Medieval Marriage Sermons. Mass Communication in a Culture Without Print (Oxford: Oxford University Press, 2001), p. 26.

${ }^{41}$ István Hajnal, L'enseignement de l'ecriture aux universités médiévales, 2nd ed., ed. László Mezey (Budapest: Maison d'Edition de l'Académie des Sciences de Hongrie, 1959), pp. 121-25.

${ }^{42}$ Colette Sirat, Writing as Handwork. A History of Handwriting in Mediterranean and Western Culture (Turnhout: Brepols, 2006), p. 479.

${ }^{43}$ For excerpts and titles from these manuals see A. S. Osley, Scribes and sources: handbook of the chancery hand in the sixteenth century (Boston: David Godine, 1980) and David Becker, The Practice of Letters. The Hofer Collection of Writing Manuals 1514-1800 (Cambridge MA: the Harvard College Library, 1997).

${ }^{44}$ Giovan Francesco Cresci, Il Perfetto Scrittore (1570), in Osley, p. 118.

${ }^{45}$ Pedro de Madariaga, Libro subtilissimo (1565), in Osley, 155.

${ }^{46}$ Erasmus, De recta Graeci et Latini sermonis pronunciatione as excerpted and translated in Osley, pp. 29-30. Cf. Quintilian: 'Writing is of the utmost importance.... But a sluggish pen delays our thoughts, while an unformed and illiterate hand cannot be deciphered, a circumstance which necessitates another wearisome task, namely the dictation of what we have written to a copyist. We shall therefore at all times and in all places, and above all when we are writing private letters to our friends, find a gratification in the thought that we have not neglected even this accomplishment.' Institutio oratoria, tr. H. E. Butler (London: William Heinemann, 1920), I.i.28-9 (I, p. $35)$.

${ }^{47}$ Osley, 41-2. 
${ }^{48}$ Francesco Sacchini, De ratione libros cum profectu legendi libellus (Ingolstadt: ex typographeo Ederiano, 1614), p. 74: 'Deinde ipsa quoque scriptio et intelligentiam iuvat.' Jeremias Drexel, Aurofodina artium et scientiarum omnium; excerpendi sollertia, omnibus litterarum amantibus monstrata (Antwerp: vidua Ioannis Cnobbari, 1638), ch. 9, p. 56: 'excerpendum esse diversis rationibus docetur. Prima est: lectoris intentio scribendi et annotandi cura multum acuitur. Altera ratio est: quod exscribitur, intelligentiam profundius subit, menti altius imprimitur. ... Cum gnaviter excerpit et annotat, crebrius subsistere cogitur et pedem figere: etiam dum lectis immoratur, dum relegit et retractat, longe melius, quae retinenda penetrat.'

${ }^{49}$ 'Itaque Demosthenes sua manu si Dionysio Halicarnasseo credimus, octies totum exscripsit Thucididem. Multa etiam manu sua exscripsit volumina S. Hieronymus: multa alij sapientissimi viri, non tam librarij inopia, quam cupiditate profectus ex opere.' Sacchini, p. 74.

${ }^{50}$ Ann Moss, Printed Commonplace Books and the Structuring of Renaissance Thought (Oxford: Clarendon Press, 1996), quotation \#125.

${ }^{51}$ Richard Steele, 'What are the Hindrances and Helps to a Good Memory in Spiritual Things?' in A Continuation of Morning-Exercise Questions ... resolved in 1682, ed. Samuel Annesley (London: J.A. Dunton, 1683), p. 428.

${ }^{52}$ G. W. J. Drewes, 'The Legatum Warnerianum of Leiden University Library', in Levinus Warner and his Legacy: Three Centuries Legatum Warnerianum in the Leiden University Library, Catalogue of the commemorative exhibition held in the Bibliotheca Thysiana from Apr. 27th till May 15th 1970 (Leiden: Brill, 1970), pp. 1-32, p. 5 and illustration on p. 79.

${ }^{53}$ I am grateful for this example to Meredith Quinn, who is studying book culture in 17th-century Istanbul and found the Ottoman collections at the Rylands Library of great interest.

${ }^{54}$ For a full description see Jan Schmidt, A catalogue of the Turkish manuscripts in the John Rylands University Library at Manchester (Leiden: Brill, 2011), pp. 303-6. Schmidt notes that the Leiden University Library owns manuscripts in which Warner gathered Turkish proverbs in draft form; a comparison of those with the Turkish sententiae in Persian MS 141 would be interesting.

55 See Franciscus de Dombay, Grammatica linguae persicae (Vienna: Albertus Camesina, 1804), available on Google Books. The Rylands manuscript grammar and the printed book differ in their breakdown of the grammatical topics and in the sample Persian texts provided. The manuscript grammar includes fifty Persian sententiae with Latin translations, while the printed grammar includes one hundred sententiae (which overlap in a few instances with the proverbs in the manuscript) but also sample dialogues, one-paragraph historiae and one-page narrationes. I am most grateful to John Hodgson for his crucial help with this comparison.

56 I rely on the expert assessment of Schmidt, Catlalogue, pp. 306, 94, 96, 102, 103, 106 (concerning Rylands Persian MSS 42, 43, 49-51). See also Jan Schmidt, "Franz von Dombay, Dragoman on the Bosnian Border, 1792-1800," in Wiener Zeitschrift für die Kunde des Morgenlandes 90(2000), pp. 75-168.

${ }^{57}$ Virginia Reinburg, French Books of Hours: Making an Archive of Prayer, c. 14001600 (Cambridge: Cambridge University Press, 2012), pp. 20-5, 76-84. 
${ }^{58}$ Rylands Latin MS 152, 'Hoc diurnale mihi fratri Ioanni Knevero ii die Dec. 1597 donatum est, a quodam parocho, cuius ut memor sim in meis preculis qualibuscunque fusis ad Dominum Deum. Amen.'

${ }^{59}$ See Elena de Laurentiis and Emilia Anna Talamo, The Lost Manuscripts from the Sistine Chapel (Madrid: Centro de Estudios Europa Hispánica and Dallas TX: Meadows Museums SMU 2011), pp. 12a, 13 b.

${ }^{60}$ See $A$ Descriptive Catalogue of Latin manuscripts, comprising a reprint of M.R. James's catalogue of 1921, ed. Frank Taylor (Munich: Kraus Reprint, 1980), vol. I, p. $87 \mathrm{fos}$, which documents the presence of the first six volumes in the Sciarra-Colonna Library until 1868 (see Additional notes, p. 19*). Rylands Latin MS 32, 32a, 33-37. The first six volumes were part of Mrs Rylands's original collection and the seventh volume was acquired at auction by the Library in August 2011. http://www.bbc.com/news/ukengland-manchester-14541766. A few pages have been digitised. http://enriqueta.man.ac.uk/luna/servlet/s/rh0exk / 7ihrm0/ h16ka6/ qy9dh2 / czw1987

${ }^{61}$ See the 'Biographical dictionary of the Cardinals of the Holy Roman Church', http://www2.fiu.edu/ mirandas/bios1517-ii.htm\#Colonna

${ }^{62}$ Latin MS 35, f. 94r, as discussed in Descriptive Catalogue of Latin Manuscripts, p. 92, also pp. 94-5.

${ }^{63}$ De Laurentiis and Talamo note how an illumination was reused by cutting and pasting, p. 39a.

${ }^{64}$ Catalogue des livres de la bibliothèque de feu M. de Lamoignon, garde des sceaux de France (Paris : Marigot jeune, 1791), II, p. 289. Chrétien-François II de Lamoignon was president of the Parlement of Paris 1758-72 and was appointed Garde des Sceaux in 1787; he died in 1789.

${ }^{65}$ Inventaire général et méthodique des manuscrits français de la Bibliothèque nationale : Jurisprudence. Sciences et arts. (Paris: H. Champion, 1878), p. 271. ${ }^{66}$ Jacob Soll, The Information Master: Jean-Baptiste Colbert's Secret State Intelligence System (Ann Arbor: University of Michigan Press, 2009), p. 65.

67 'Il existe une représentation assez médiocre de la façade des Invalides et une gravure intéressante de la partie centrale du château de Versailles dans un autre placard, qui a pour titre : Abrégé chronologique des roys de France, instructif et récréatif, ou l'on apprendra en jouant ce qui s'est passé de plus curieux sous chaque regne, ouvrage orné de symboles, hiéroglyphes et attributs convenables a l'histoire..., par le sieur du Tertre, orné et dessiné par de Phainx fils, gravé par Fombone, écrit par Jenvilliers, 1730.' Bulletin de la Société de l'histoire de Paris et de l'Ile-de-France, vol. 23-6. (1896), p. 80. And see the catalogue of the Bibliothèque nationale de France: Discours instructif qui sert d'explication aux ornemens du jeu chronologique et historique des roys de France... $d u$ Sr Du Tertre (printed without place or date), with this note: 'Le jeu, intitulé "Abrégé chronologique des roys de France, instructif et récréatif," et dessiné par de Phainx fils en 1730, est conservé au Dép. des Estampes, supplément non relié.' I am grateful for these finds to Samantha Wesner.

${ }^{68}$ For an entry into the manuscripts of early modern alchemy see George Starkey, Alchemical Laboratory Notebooks and Correspondence, ed. William R Newman and Lawrence Principe (Chicago: University of Chicago Press, 2004). 